\title{
A Case of Unusual Type of Branchial Cleft Cyst Presenting as Superficial Midline Neck Mass
}

\author{
Hun Hee Baek ${ }^{1}$, Sung Hwan Lim ${ }^{1}$, Mi Ji Lee ${ }^{2}$, and Seung Woo Kim ${ }^{1}$ \\ ${ }^{1}$ Departments of Otolaryngology-Head and Neck Surgery, ${ }^{2}$ Pathology, Veterans Health Service Medical Center, Seoul, Korea
}

\section{천층 정중부 경부 종물 양상의 드문 형태의 새열낭종 1 예}

백훈희 $^{1} \cdot$ 임성환 $^{1} \cdot$ 이미지 ${ }^{2} \cdot$ 김승우 $^{1}$

중앙보훈병원 이비인후과, ${ }^{1}$ 병리과 ${ }^{2}$

\author{
Received April 25, 2017 \\ Revised May 29, 2017 \\ Accepted June 12, 2017 \\ Address for correspondence \\ Seung Woo Kim, MD \\ Department of Otolaryngology- \\ Head and Neck Surgery, \\ Veterans Health Service \\ Medical Center, \\ 53 Jinhwangdo-ro 61-gil, \\ Gangdong-gu, Seoul 05368, Korea \\ Tel $+82-2-2225-1384$ \\ Fax $+82-2-2225-1385$ \\ E-mail entzzang1020@daum.net
}

The most widely accepted hypothesis about the origin of branchial cleft cysts (BCC) is developmental theory. The second most accepted is acquired inflammatory theory. A 57-year-old woman visited our department, presenting with a soft and well-margined round superficial mass in the lower midline neck. We performed an excisional biopsy to confirm the disease. The mass was located superficial to the sternohyoid without severe adhesion and abnormal communication. The pathology was proven to be BCC. We presumed that this is irrelevant to the established developmental theory, and a recurrent pharyngeal inflammation might lead to the transformation of aberrant epithelium into a cervical lymph node. We report rare and unusual type of BCC with a literature review. To the best of our knowledge, there have been two similar clinical cases that have been reported earlier.

Korean J Otorhinolaryngol-Head Neck Surg 2017;60(12):678-80

Key Words Branchial cleft cyst · Inflammation · Midline $\cdot$ Neck.

\section{서 론}

새성 기형은 경부에 발생하는 두 번째로 흔한 선천성 병변 으로 태생 2개월에 폐쇄되는 새성 기관(branchial organ)의 발생학적 이상으로 낭, 루 그리고 동 등의 기형이 형성되는 것 을 지칭한다. ${ }^{1,2)}$ 새열낭종의 경우 대부분 측경부에 무통성, 단 발성으로 발생하며, ${ }^{3)}$ 원인으로 가장 인정되는 가설은 발생학 적 이상으로 새성기관의 상피 조직이 잔류해서 형성된다는 주 장이다.) 그러나 후천적으로 반복되는 감염에 의해, 인두의 편평상피가 림프계를 통하여 국소 림프절로 이동하여 발생 한다는 주장도 있다.4) 특히 이런 경우에 낭종이 특이한 위치 및 임상 양상을 보일 수 있다. 저자들의 국내 및 영문 논문 검

This is an Open Access article distributed under the terms of the Creative Commons Attribution Non-Commercial License (http://creativecommons.org/licenses/by-nc/4.0) which permits unrestricted non-commercial use, distribution, and reproduction in any medium, provided the original work is properly cited.
색으로는 하부 경부의 정중부 표층에서 발생한 새열낭종은 지금까지 2예가 보고되었다. ${ }^{5,6)}$ 저자들은 우측 하부 천층 중심 경부의 종물을 주소로 내원한 57세 여자 환자에서 새열낭종 으로 확진된 매우 드문 증례를 문헌 고찰과 함께 보고하고자 한다.

\section{증 례}

57세 여자 환자가 내원 3년 전부터 크기가 증가하는 우측 전 경부 종물을 주소로 내원하였다. 신체검사에서 우측 하부 전 경부에 경계가 명확하고 약간의 가동성 있는 $1.5 \times 2 \mathrm{~cm}$ 크기 의 부드러운 종물이 촉지되었고, 연하 시에 종물의 가동성은 없었다(Fig. 1). 환자는 3년 동안 종물 부위의 염증으로 인한 징후 및 증상은 없었다고 한다. 먼저 영상학적 평가를 시행 하였다. 초음파검사에서 $1.3 \times 2.2 \mathrm{~cm}$ 크기의 우측 흥설골근의 


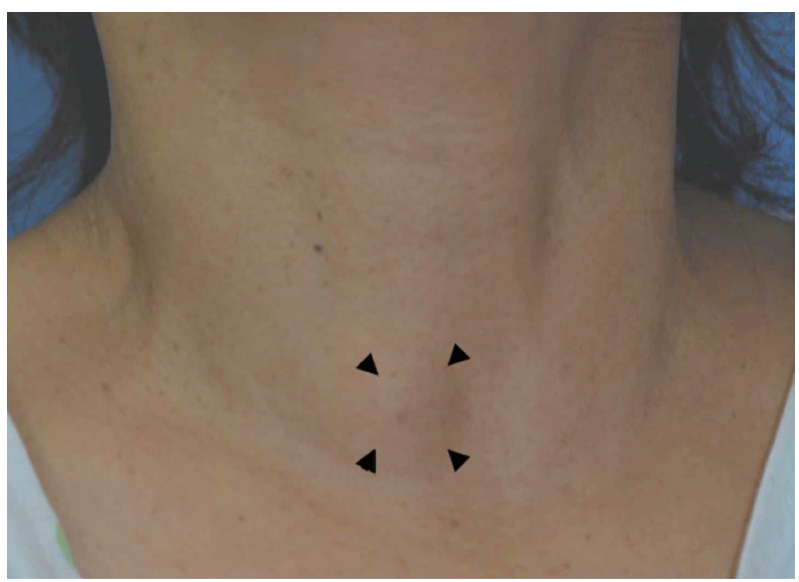

Fig. 1. External photograph. It shows $2 \times 2 \mathrm{~cm}$ sized, soft, round, slightly movable and non-tender mass, which did not move with swallowing (arrowheads).
천층에 경계가 명확한 혼합형 에코 소견이 있었고(Fig. 2A), 전산화단층촬영에서는 종물의 정확한 경계는 그려지지 않으 나, 우측 피대근이 건측에 비해서 미만성으로 돌출된 양상이 었다(Fig. 2B). 초음파 유도하 세침흡인세포검사에서는 소량 의 림프구만 관찰되었다.

이런 소견을 종합하여 양성 낭성종물, 표피낭종, 염증성 가 성 종양 및 결절성 근막염 등을 의심하고, 국소 마취하에 절 제 생검을 시행하였다. 종물이 촉진되는 부위 위를 절개하고 피부 피판을 거상했다. 종물은 우측 흥설골근과 경한 유착 이 있었으나 비교적 쉽게 박리되었다(Fig. 2C). 수술 시 종물 의 주변에 다른 부위로 연결된 비정상적인 동이나 누공 같은 소견은 없었다. 병리 소견에서 낭포성 상피 세포는 중층편평 및 섬모원주 상피 세포로 구성되어 있었고, 소량의 림프성 침
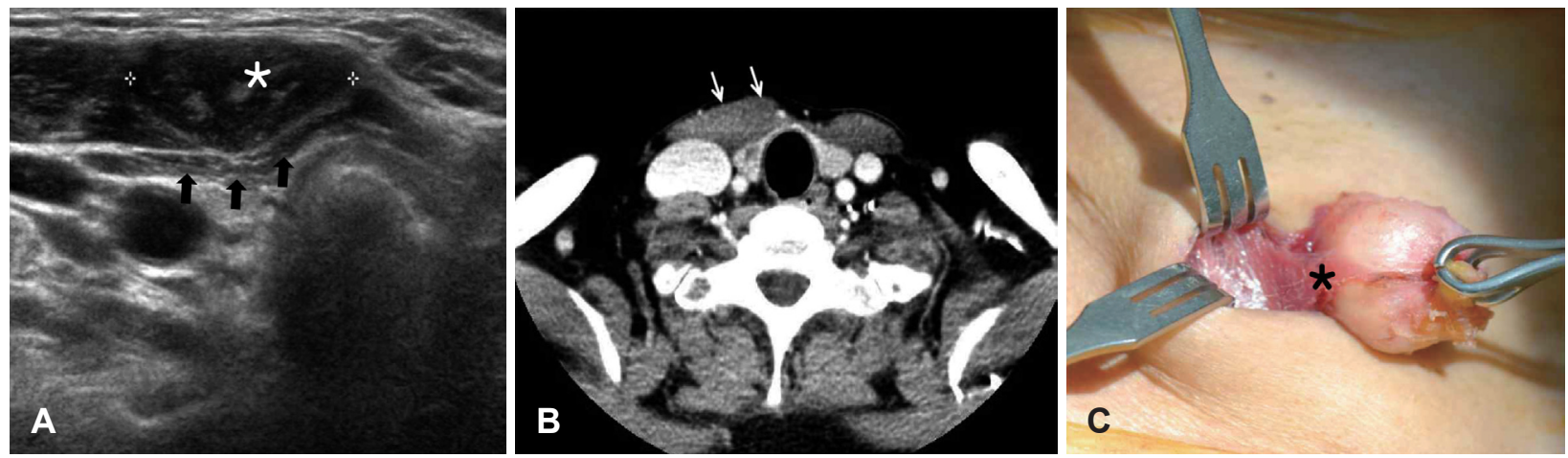

Fig. 2. Transverse scan of ultrasonography shows $2.2 \times 1.3 \mathrm{~cm}$ sized, well-defined heterogeneously hypoechoic mass (asterisk) above the right sternohyoid (arrows) (A). The contrast-enhanced axial image of computed tomography revealed that focal bulging of the strap muscle is observed without obvious shadow of mass (arrows) (B). Intraoperative findings. It shows well-margined, smooth and round mass slightly adherent to the sternohyoid (asterisk) (C).

Fig. 3. Cut surface of the specimen showed that the uni-locular cyst measures $2.5 \times 2.0 \times 1.5 \mathrm{~cm}$ and the inner cystic surface contains yellowish white cheezy material (A). The thin cystic wall is observed without nodular excrescences in low power view (H\&E, $\times 40)(B)$. Cystic lining epithelium consists of stratified squamous epithelium (square) (H\&E, $\times 200)(C)$. Cystic lining epithelium consists of ciliated columnar epithelium (arrows). In the fibrous cystic wall, a little lymphoid infiltrates (encircled in black) are multi-focally observed beneath the lining epithelium $(H \& E, \times 200)$ (D).
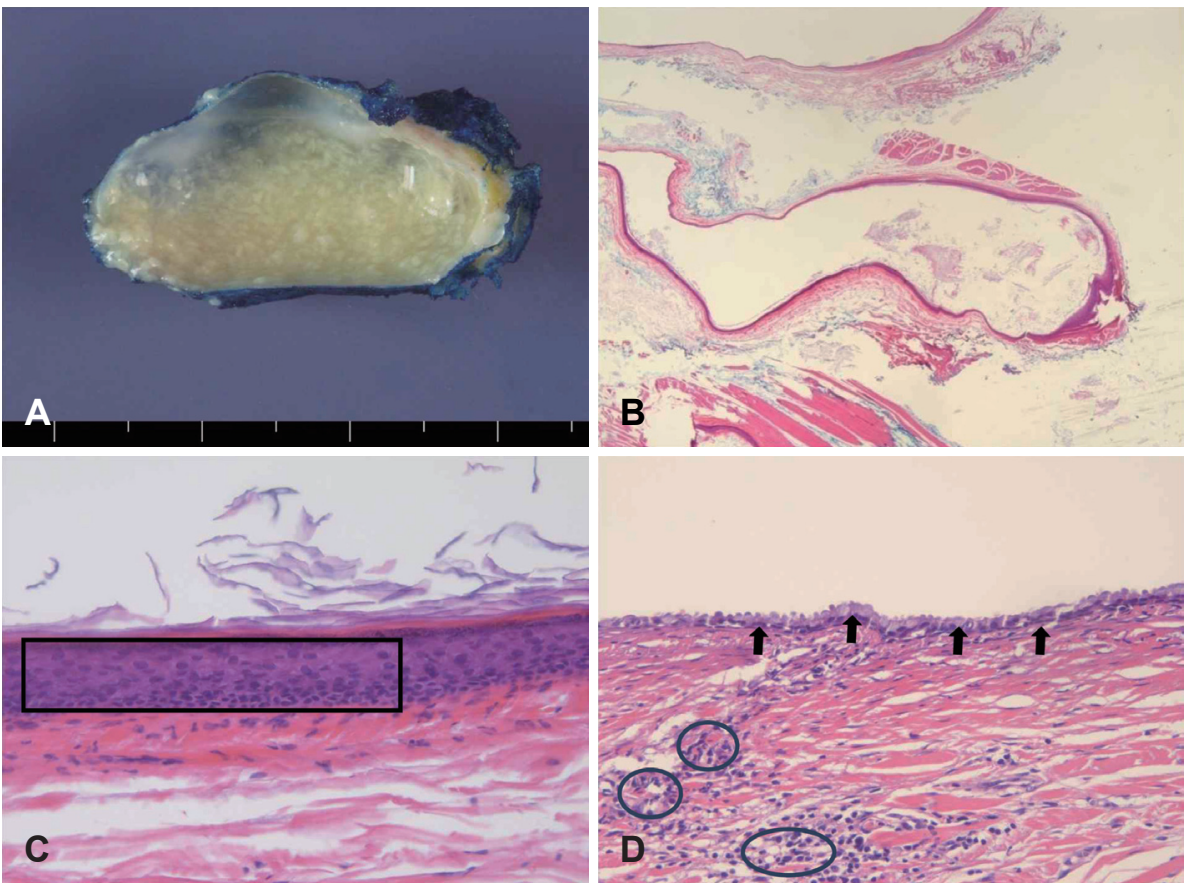
윤이 점막 상피층에서 다발성으로 관찰되어 새열낭종으로 확 진되었다(Fig. 3). 환자는 술 후 1년 동안 재발 소견 없이 추적 관찰 중이다.

\section{고 찰}

새열낭종은 고전적으로 4가지 형태로 분류되어 왔고, 이 중 제2형이 $90 \%$ 이상이다.' 1 형과 2형 새열낭종은 일반적으로 상 부 측경부에 나타나며, 3형과 4형은 상대적으로 드물고 대부 분 하부 경부의 좌측에서 발견된다. ${ }^{3)}$ 제 3 형은 흥쇄유돌근의 전방에 피부와 연결이 있으며, 4형은 이상와의 첨부에서 누공 로가 시작된다. ${ }^{3)}$

새열낭종은 중층편평 또는 원주 상피 세포로 둘러싸인 낭 종이 조직학적 특징이며, 비각화 편평상피로 구성되는 비율이 $90 \%$ 정도이다. ${ }^{2}$ 낭종의 벽에는 다양한 양의 림프 조직이 존재 하며, 상피 아래에는 종자중심(germinal center)이 종종 관찰 된다. ${ }^{2}$ 림프 조직이 소량인 새열낭종은 전체의 $3.4 \%$ 정도로 매 우 드물다. ${ }^{4)}$ 본 증례도 소량의 림프 세포가 상피 조직 아래에서 산발적으로 관찰되었으며, 이러한 병리 소견이 림프상피성 낭 종이나 림프절의 낭성 변화와는 감별점이 된다. ${ }^{7)}$

새열낭종의 발생기전에 대해서는 아직까지 논란이 있으며, 선천적과 후천적 원인설이 있다. 전자에는 새열형성 기관의 발생 과정 이상, 발생 과정에서 림프절 내부로 상피 세포의 함 입, 경부 동 가설(cervical sinus theory), 흥선-인두관 형성 과 정의 이상 등 네 가지 가설이 있다. ${ }^{8)}$ 후자는 반복되는 감염에 의하여 발다이어 고리(Waldeyer's ring)의 이소성 선상피가 구 강의 림프양 조직으로 함입되어 림프계를 통해서 국소 림프 절로 이동 및 증식할 수 있으며, 또한 낭종이 구강에 발생하 는 경우 정상 편도음와(crypt)의 폐색에 의해 발생할 수 있다 는 가설이다. ${ }^{4,910)}$ 새열낭종과 상기도 상피에 특이적인 케라틴 이 생화학적으로 동일하다는 연구결과가 이 후천적 가설을 뒷 받침한다. ${ }^{11,12}$

새열낭종이 후경부 삼각, 이하선, 종격동 및 비인두 등과 같 은 곳에서의 발생이 보고되었으며, 이런 경우는 발생학적 가 설로 설명하기 어렵다., ${ }^{1,8,13,14)}$ 저자들의 영문 검색에서 본 증례 와 유사하게 천층 정중부에 발생한 경우는 매우 소수였다. ${ }^{5,6)}$ 일반적으로 50 대에 새열낭종이 발견되는 경우는 $1.2 \%$ 로 보 고돼 있다." ${ }^{4}$ 본 증례는 50대 후반에서 인지되었으며, 하부경
부 천층의 우측 정중부에 발생하였고, 다른 주변 구조물과 연결된 동이나 누공이 없다는 점도 후천적인 원인에 의한 병 인을 시사한다.

새열낭종은 세침흡인검사로 확진이 어렵고 재발 가능하며, 낭종 내부에 갑상선 유두상암종이 발견될 수 있어 외과적 절 제술이 필수적이다. ${ }^{15)}$ 천층 정중부 경부 종물의 경우 감별진 단으로 새열낭종을 고려해야 하며, 유사한 증례의 수집과 연구 를 통해 비전형적 새열낭종의 발생기전에 대한 연구가 더욱 필요하다.

\section{REFERENCES}

1) Panchbhai AS, Choudhary MS. Branchial cleft cyst at an unusual location: a rare case with a brief review. Dentomaxillofac Radiol 2012; 41(8):696-702.

2) Zaifullah $S$, Yunus MR, See GB. Diagnosis and treatment of branchial cleft anomalies in UKMMC: a 10-year retrospective study. Eur Arch Otorhinolaryngol 2013;270(4):1501-6.

3) Srinjeeta G, Yuvraj P, Karan V, Adip S, Haritosh V. Third branchial cleft cyst presentation in adulthood: a case report. Otolaryngol Online J 2014;4(4):191.

4) Bhaskar SN, Bernier JL. Histogenesis of branchial cysts; a report of 468 cases. Am J Pathol 1959;35(2):407-43.

5) Mallikarjunappa AM, Prakash NS, Shamna M, Lavanya K. Branchial cleft cyst - a rare presentation. J Pub Health Med Res 2014;2(1):48-9.

6) Aggarwal S, Garg P, Bhoriwal S, Rathee VS, Verma S, Mitta S, et al. Branchial cyst in the midline of the neck: a first case report in the literature. Internet J Otorhinolaryngol 2013:15(1):1-4.

7) Hirota J, Maeda Y, Ueta E, Osaki T. Immunohistochemical and histologic study of cervical lymphoepithelial cysts. J Oral Pathol Med 1989;18(4):202-5.

8) Upile T, Jerjes W, Al-Khawalde M, Kafas P, Frampton S, Gray A, et al. Branchial cysts within the parotid salivary gland. Head Neck Oncol 2012;4:24.

9) Drumm AJ, Chow JM. Congenital neck masses. Am Fam Physician 1989;39:159-63.

10) Bhaskar SN. Lymphoepithelial cysts of the oral cavity. Report of twentyfour cases. Oral Surg Oral Med Oral Pathol 1966;21(1):120-8.

11) Wild G, Mischke D, Lobeck H, Kastenbauer E. The lateral cyst of the neck: congenital or acquired? Acta Otolaryngol 1987;103(5-6):546-50.

12) Wild GA, Wille G, Mischke D. Lateral cervical (branchial) cyst epithelia express upper digestive tract-type cytokeratins. Polyclonal antibody studies. Ann Otol Rhinol Laryngol 1988;97(4 Pt 1):365-72.

13) Tanaka H, Igarashi T, Teramoto S, Yoshida Y, Abe S. Lymphoepithelial cysts in the mediastinum with an opening to the trachea. Respiration 1995;62(2):110-3.

14) Chen PS, Lin YC, Lin YS. Nasopharyngeal branchial cleft cyst. J Chin Med Assoc 2012;75(12):660-2.

15) Sagit M, Gokler A, Akin I, Han U. Wrong egg in the usual nest: thyroid papillary carcinoma within a branchial cleft cyst. Ear Nose Throat $\mathrm{J}$ 2013;92(7):E31-4. 